\title{
The characteristics of Triassic detrital components and provenance analysis in the western Tabei Uplift
}

Yanqiang $\mathrm{Chi}^{1}$, Jingyan $\mathrm{Liu}^{1}$, Changsong Lin ${ }^{2}$, Yongfu Liu ${ }^{3}$, Xiaoni Wang ${ }^{1}$

1. School of Energy Resources, China University of Geosciences, Beijing, China

2. School of Ocean Sciences and Resources, China University of Geosciences, Beijing, China

3. Research Institution of Petroleum Exploration and Development, Tarim Oilfield, Xinjinag, China

KEYWORD: detrital component characteristics; provenance analysis; Triassic.

ABSTRACT: Triassic in the western Tabei uplift is detrital sedimentary. Based on the data of the conglomerate, sandstone framework components and heavy mineral to analyze the Triassic of research area, the result shows that the source rocks are metamorphic rocks, magmatic rocks and sedimentary rocks, whose sources come from Xiqiu Uplift and Luntai Uplift. The western of research area is magmatic and sedimentary rock deposit zone, where is mainly influenced by the Xiqiu Uplift. The middle part of research area is metamorphic and sedimentary rock deposit zone where is mainly influenced by the Xiqiu Uplift and Luntai Uplift. The eastern of research area is metamorphic, sedimentary and magmatic rock deposit zone where is mainly influenced by the Luntai Uplift. The proximal clastic deposits are mainly influenced by the hydrodynamic conditions, palaeohigh and tectonization, so provenance has the characteristics of region and multiple evolutions.

\section{INTRODUCTION}

Triassic develops widely in the western Tabei uplift where the mudstone has a heavy thickness, so it is considered the fantastic source rock. Former researchers mainly take advantage of the sandstone framework components to analyze the Mesozoic provenance in the Kuqa Depression [Cao Shoulian, 1994][Zhang Ximing, 1995][Zhao Xuesong, 2014]. Based on abundant drilling cores, seismology and well-logging information, a series of work of geological documentation of drill core, thin slice identification and heavy mineral analysis have been done to reveal the source rock types and provenance of Triassic in the western Tabei Uplift and discuss the main controlling factors of the proximal clastic deposit.

\section{GEOLOGICAL SETTING}

The western Tabei Uplift was part of Tabei Frontal Uplift during the late Hercynian- Indochina orogeny, which was one of areas in Tabei Uplift [Jia Chengzao, 1999][He Dengfa, 2005]. During the late Hercynian orogeny, Tabei palaeohigh had basically finalized, with the tectonism being stronger from east to west. Strong erosion exposed Precambrian in the Luntai Uplift. In the study area, the Cenozoic in the structural highs was the direct unconformity above the Cambrian-Ordovician carbonate rocks. During early Indochina movement, Luntai Uplift was gradually flattened as the source area. The west of Tabei uplift suffered massive volcanic activities, which was caused by the southern Tianshan orogeny collision and extrusion.

\section{DETRITAL COMPOSITION ANALYSIS}

Debris is affected by many factors at the process of weathering, erosion, transportation and deposition, which are provenance, climate, tectonism and hydrodynamic conditions. The source 
rock plays a decisive role, so we can analyze its provenance by studying detrital compositions. The paper is based on more than 40 boreholes cores and thin slice to identify and analyze conglomerate, sandstone framework components and detrital heavy minerals.

\subsection{Conglomerate analysis}

In clastic sediments, conglomerate contains massive information of source rock because of its specificity, which is the most direct reflection of the types of mother rock. The composition analysis has a great effect to study the evolution of provenance. The western Tabei uplift developed several layers of Triassic conglomerates. Conglomerate mainly consists of quartz, chert and sandyconglomerate, and some are mud gravels, igneous gravels and carbonate gravels. The grain size is generally $3 \sim 5 \mathrm{~mm}$, part of 15 20mm; general sorting, sub-angular, sub-rounded; most of the sandy cementation, shale filling. The analysis results show that debris is proximal clastic deposit.
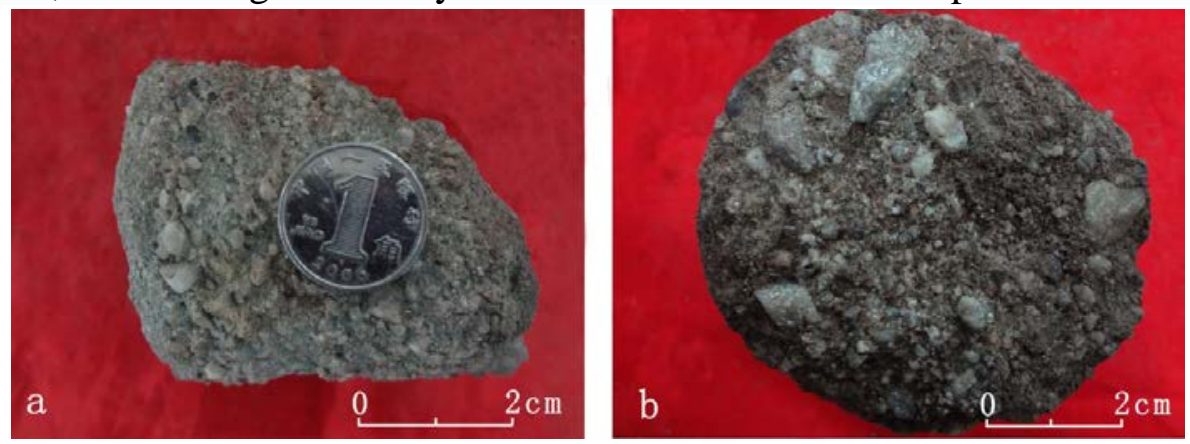

Figure 1.The western Tabei Uplift Triassic conglomerate: a-Kelamayi Formation from yt8 borehole, main of quartz gravel, part of igneous gravel; b-Ehuobulake Formation from ym5 borehole, main of quartz gravel, some chert gravel

Through the statistics of frequency which the mainly gravel composition of conglomerate appears in each well (Table 1), the results are below.

In the lower Triassic, conglomerate is mainly composed of quartz, mudstone and volcanic gravel, which shows that the Permian volcanic rock has begun to be eroded.

In the middle Triassic, conglomerate mainly is composed of quartz, chert and sandyconglomerate, part of a few mudstone and carbonate gravel. However, the content of igneous gravel is obvious more than the lower Triassic which indicates volcanic rock has suffered strong erosion. Mudstone gravel and sandyconglomerate are rich, which indicates that the speed of accumulating of sediment is fast, and the uplift is very intense in the source area. The appearance of carbonate rock shows that it has been one of the main sources which reflect the surrounding Paleozoic suffers further erosion.

In the upper Triassic, conglomerate mainly is composed of quartz, metamorphic gravel and a few of mudstones gravel. And the changes are that: the appearance of metamorphic rocks indicates metamorphic rocks of the crystalline basement uplift and orogenic activity strengthen, which may be related to the activity of Luntai Uplift; the non-existence of volcanic rock indicates Permian volcanic rock is no longer the main source, and provenance has penetrated the Permian.

Table 1. The gravel composition frequency statistics of the western Tabei Uplift

\begin{tabular}{lccccccc}
\hline & Metamorphic & Carbonate & Chert & Quartz & Glutenite & $\begin{array}{c}\text { Argillaceous } \\
\text { rocks }\end{array}$ & Volcanic \\
\hline $\begin{array}{l}\text { Late Triassic } \\
\text { Middle }\end{array}$ & 3 & 0 & 0 & 4 & 1 & 2 & 0 \\
$\begin{array}{l}\text { Triassic } \\
\text { Early }\end{array}$ & 0 & 4 & 16 & 35 & 12 & 5 & 3 \\
Triassic & 0 & 1 & 2 & 9 & 2 & 3 & 3 \\
\hline
\end{tabular}




\subsection{The analysis of sandstone framework component}

Based on the research of 10 wells of Triassic sandstone thin slices, a total of more than 240 sections were observed, aiming to study the source of the Triassic area type. According to the provenance triangle [Dickinson, 1979], the region is the main source of stable continental block provenance, part of recycled orogeny belt provenance and magmatic provenance. The sorting of particles and poor roundness shows that it is the proximal clastic deposit. Feldspar alteration is strong and has clayzation, resulting in feldspar content relatively reduce and the unstable debris content relatively increase, which makes some samples fall into the cycle orogeny belt provenance. The volcanic rock content from the Permian effusive rocks is relatively higher, combined with the geological background of the area, which is special in this area. According to the above factors, this source region is mainly the stable continental block provenance and Xiqiu Uplift and Luntai Uplift are its sources.

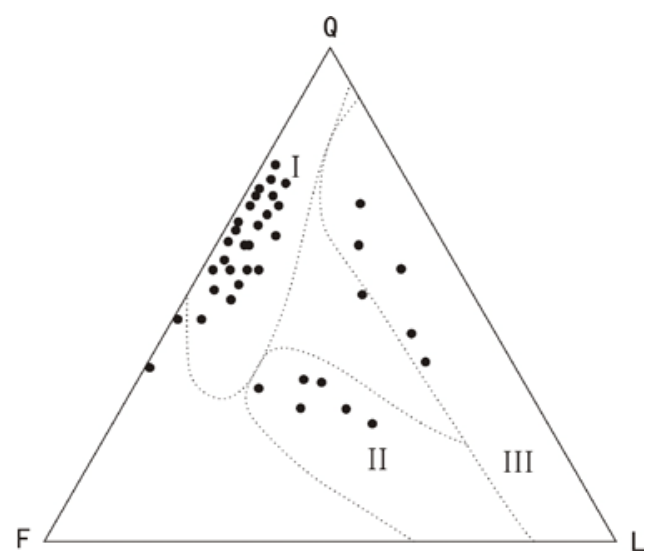

Figure 2. The Triassic sandstone framework composition and provenance type triangle map of Western Tabei

I —stable continental block provenance; II —magmatic provenance; III—recycled orogeny belt provenance

\subsection{Analysis of detrital heavy minerals}

The source rock plays a decisive role in the heavy mineral composition. In the same sedimentary basin, the characteristics of heavy mineral composition are similar. The heavy mineral test on 30 samples of 6 wells in the study area shows that the detrital composition of sandstone is complex.

Table 2. The table of heavy mineral percentage

\begin{tabular}{lr||lr}
\hline Heavy mineral & \multicolumn{1}{c||}{$\begin{array}{l}\text { The average mass } \\
\text { fraction (\%) }\end{array}$} & $\begin{array}{c}\text { Heavy } \\
\text { mineral }\end{array}$ & $\begin{array}{c}\text { The average mass } \\
\text { fraction (\%) }\end{array}$ \\
\hline Garnet & 18.68 & Barite & 4.93 \\
Pyrite & 18.10 & Apatite & 2.39 \\
Hematite and & 16.28 & Tourmaline & 0.63 \\
Limonite & 10.90 & Rutile & 0.45 \\
Zircon & 8.00 & Epidote & 0.44 \\
Leucoxene & 7.37 & Staurolite & 0.08 \\
Ilmenite & 6.21 & & \\
Magnetite & &
\end{tabular}

\subsubsection{Analysis of heavy mineral provenance}

Combinatory analysis was carried by major heavy mineral combination, which can be divided into three categories: F1 represents the combination of ilmenite, leucoxene and garnet; F2 
represents the assemblage of apatite and pyrite; F3 represents the assemblage of barite and zircon. According to common mineral assemblage types and rock types [Pettijohn, 1975], it shows that the types of source rock of F1, F2 and F3 are respectively metamorphic rocks, magmatic rocks and sedimentary rocks.

Through the analysis of wells distribution of the combination of F1, F2, F3 (Figure 3), provenance types can be divided into following three types. In the western region, influenced by the Xiqiu Uplift, Permian magmatic rocks widely developed in this area, so the magmatic composition of detrital heavy minerals had a large proportion. In the middle region of metamorphic and sedimentary rock area, magmatic proportion was relatively small. In the Xiqiu Uplift and Luntai Uplift binding site area, tectonic position gradually increased and the Luntai Uplift suffered strong erosion in the late Hercynian, which exposed the Precambrian metamorphic rocks. Early Indosinian tectonic movement made the Luntai Uplift again suffers strong denudation again, so heavy mineral composition came from Luntai Uplift and Xiqiu Uplift. Combined with the regional geological background, the eastern of the region is the mixture of source rocks, which developed metamorphic rocks, magmatic rocks and sedimentary rocks, mainly affected by Luntai Uplift. Its distribution range is significantly influenced by the properties of source rocks.

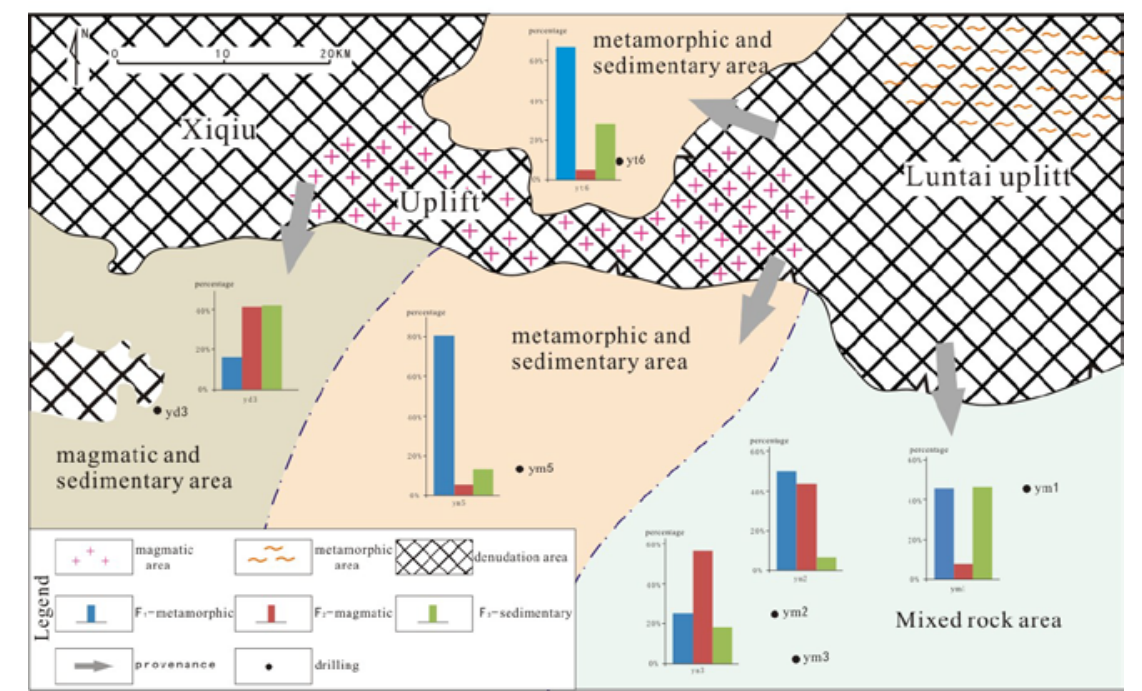

Figure 3. The Triassic provenance types and distribution map of the western Tabei Uplift

\subsubsection{Heavy mineral ZTR index analysis}

The ZTR index consists of mineral content of zircon, tourmaline and rutile. The smaller index represents the closer distance from the source; otherwise the distance is away from the source. Therefore, it is an important data for studying the provenance. Based on a large number of cores of heavy mineral analysis and the calculation of ZTR, this study has drawn the ZTR contour map (Figure 4).Then, according to the content distribution of conglomerate, sandstone and siltstone, the results show that there is a good matching relationship between ZTR contour and distribution of detrital particle. Near the Xiqiu Uplift and Luntai Uplift, detrital grain size is large and the ZTR value is relatively low; away from the Uplift area, detrital grain size is relatively small and the ZTR value increases gradually. ZTR index of sample between 4.4-14.7, the value is relatively low, which shows the characteristics of proximal clastic deposit and further confirms that the provenance comes mainly from Xiqiu Uplift and Luntai Uplift. 


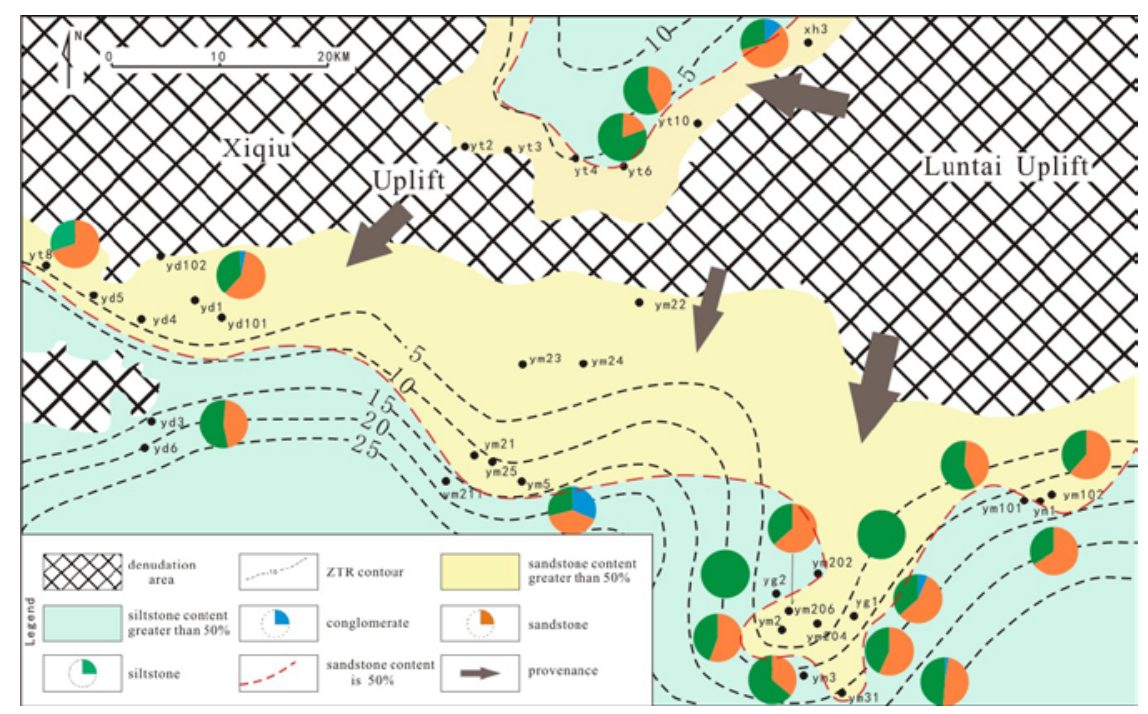

Figure 4. The heavy mineral ZTR contour map of the western Tabei Uplift

\section{THE DISCUSSIONS ABOUT THE CONTROL FACTORS OF THE PROXIMAL CLASTIC DEPOSIT}

Detrital component is influenced by various factors during the process of weathering, denudation, transportation and deposition which will lead to the great difference to its components. The research area closes to palaeohigh and its characteristics of detrital component conforms to the features of proximal clastic deposit. This research has summarized the proximal clastic sediments provenance of the western Tabei Uplift and its three kinds of control mode to the sedimentary basin infilling.

As shown in the figure 5-a, because structural relief is not very obvious, Permian begun to be worn away in the Xiqiu Uplift and Luntai Uplift. The single hydrodynamic system sedimentary area which is controlled by the Xiqiu Uplift will generate single provenance Ia. The single hydrodynamic system sedimentary area which is controlled by the Luntai Uplift will generate single provenance Ib. Due to the hydrodynamic system coming from two directions, the combining site of the uplift will generate mixture provenance. Because Xiqiu Uplift can develop magmatic rocks, the character of palaeohigh is different which would lead to the clastic component difference between Ia and Ib. In the mixture provenance ,Ithe provenance comes from two directions, so the characteristics of its clastic component will contain some characteristics of the Ia and Ib and the mixture provenance II regarded as the transition region of Ia and Ib.

In the figure 5-b, because of tectonic movement, the Xiqiu Uplift begins to ascend. Permian widespread suffers from erosion and then the well-developed magmatite is also denudated. The Luntai Uplift rises even more intensively, it not only denudates the Permian, but the Silurian-Carboniferous, even the carbonate rocks of Cambrian-Ordovician, in the structural higher position. Consequently, in the clastic component of single provenance Ia, the proportion of magmatite has increased. The clastic component of single provenance Ib is characterized by containing the carbonate component. The clastic component of mixture provenance characterized by containing the magmatic and carbonate component simultaneously.

In the figure 5-c, due to the further aggravation of tectonic movement, the Xiqiu Uplift and Luntai Uplift continue to rise. At the moment, Xiqiu Uplift starts to denudate the debris of Silurian-Carboniferous and the carbonatite of the Cambrian-Ordovician. In the higher structural position even has denudated the metamorphic crystalline basement. In the single provenance Ia, the clastic component is characterized by excluding magmatic component. In the single provenance Ib, 
clastic component is characterized by containing abundant carbonate component and a part of metamorphic component, while the mixture provenance II is characterized by the a bit of carbonate and metamorphic component.

Through the analysis above, the hydrodynamic condition, palaeohigh and tectonic movement of the proximal clastic deposit has controlled the characteristics of clastic component. The hydrodynamic is direct influence factor, and the palaeohigh is indirect influence factor. Both of them are crucial for the characteristics of clastic component, while the tectonic movement affects the characteristics of clastic component by controlling the variation of palaeohigh. The hydrodynamic system comes from single palaeohigh, which makes the provenance of deposit zone relative singularity. At the moment the difference of palaeohigh will lead to the difference of the clastic component of the sedimentary area. At the intersection of palaeohigh or at the intersection of hydrodynamic system which comes from various directions will make the sedimentary area turn into mixture source area, in this way provenance will have the regional characteristic. The tectonic movement has multiple evolutions, so it will also lead to the multiple evolution of provenance. With a short period of time, the deposit zone is mainly controlled by the hydrodynamic system and palaeohigh, while in the large scale of time, tectonic movement also has a big influence to provenance. In conclusion, the provenance has the characteristics of region and multiple evolutions. When we analyze the provenance of clastic component, it is necessary to fully consider the features of research area and the time scale.
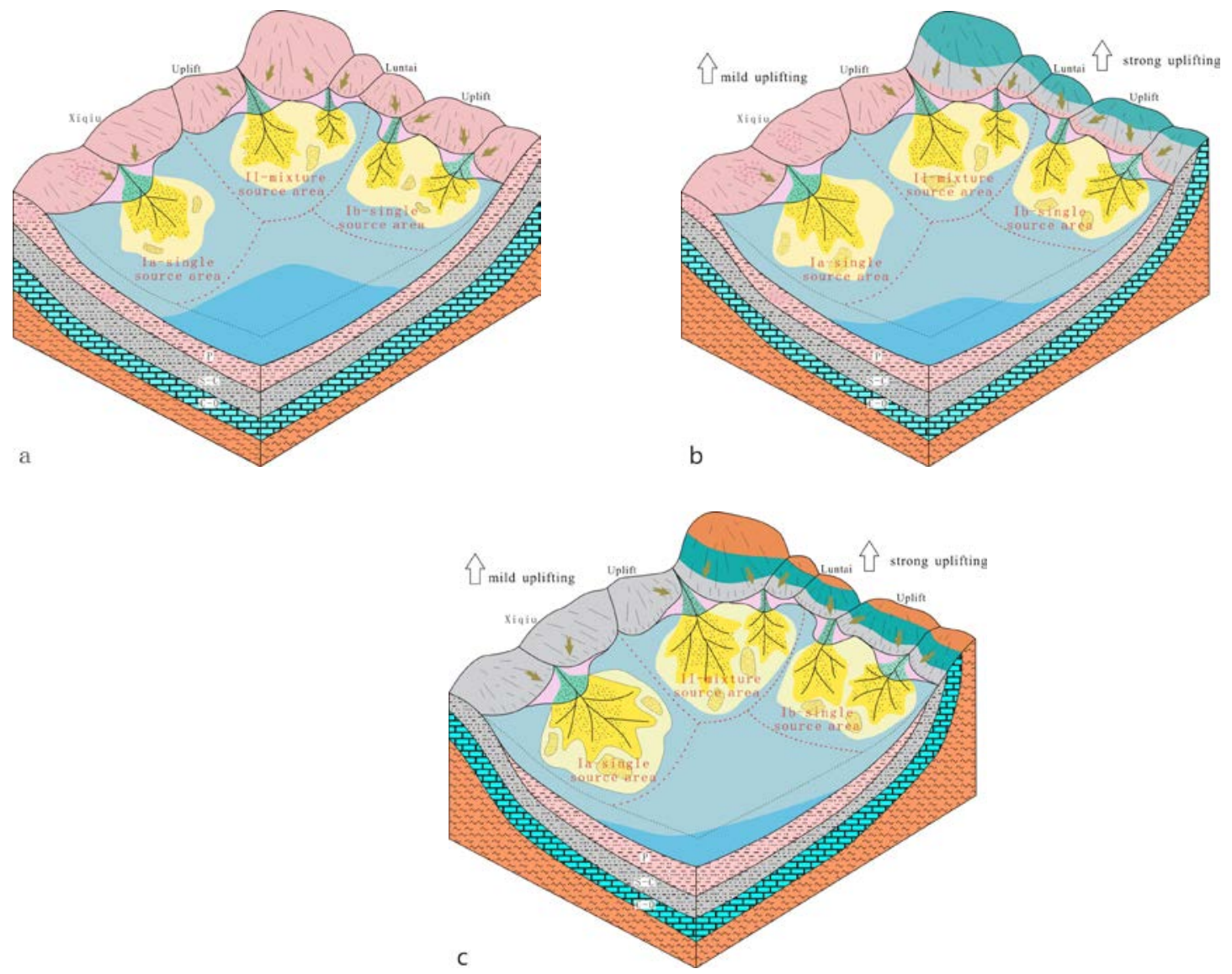

Figure 5. The mode map of the provenance control factors of proximal clastic sediments

\section{CONCLUSIONS}

(1) The western Tabei Uplift of Triassic conglomerate is composed of mainly quartz, flint and sandyconglomerate. It is proximal clastic deposit. The sandstone framework components mainly 
distributes in the stable continental block provenance, part of the recycled orogeny provenance and magmatic provenance, which reveals the provenances come from Xiqiu Uplift and Luntai Uplift.

(2) Heavy mineral components of type are complex, which reveals the main source rocks are metamorphic, magmatic and sedimentary rocks. The western of research area is magmatic and sedimentary rock deposit zone, where is mainly influenced by the Xiqiu Uplift. The middle part of research is metamorphic and sedimentary rock zone where is mainly influenced by the Xiqiu Uplift and Luntai Uplift. The eastern of research area is metamorphic, sedimentary and magmatic rock zone where is mainly influenced by the Luntai Uplift. ZTR index distribution of heavy minerals has a very good relationship with particle size distribution of sandstone.

(3) The proximal clastic deposits are mainly controlled by hydrodynamic conditions, paleouplift and tectonic movements. Hydrodynamic condition is direct influencing factor, and paleouplift is indirect factor. Both of them have a decisive impact on the characteristics of detrital composition. Tectonic movements, by controlling paleouplift, influence the characteristics of detrital composition. Thus, provenance has the characteristics of region and multiple evolutions.

\section{ACKNOWLEDGEMENTS}

This work was supported by the National Natural Science Foundation of China (Grant No.41130422) and National Science and Technology Major Project (No. 2011ZX05003-002). We are grateful to Prof. Jingyan Liu as main editor for the critical and encouraging comments on the manuscript.

\section{REFERENCES}

[1]Zhao Xuesong et al. 2014. Triassic-Neogene Heavy Minerals Assemblages Characteristics and Basin-Orogen Tectonic Evolution Relationship in the Kuqa Foreland Basin. Acta Sedimentologica Sinica 32(1).

[2]Cao Shoulian et al. 1994. Provenance analysis of the basin-deposited sequence in the Northeast Tarim. Xinjiang Geology 12(3):201-208.

[3]Zhang Ximing et al. 1995. Triassic-Jurassic sandstone fragment components related with pate tectonic position in the northern Tarim basin. Xinjiang Geology 13(3):251-255.

[4]Jia Chengzao. 1999. The structural characteristics and oil and gas accumulation in Tarim basin. Xinjiang Petroleum Geology 20(3):177-183.

[5]He Dengfa et al. 2005. Formation and evolution of polycyclic superimposed Tarim Basin. Oil \& Gas Geology 26(1):64-77.

[6]Dickinson W R et al. 1979. Plate tectonics and sandstone compositions. Aapg Bulletin 63(12): 2164-2182. 